\title{
Private Information in Bank Certification: Evidence from U.S. and Non-U.S. Bank Standby Letters of Credit
}

\author{
Roger D. Stover \\ Iowa State University, U.S.A. \\ Mark F. Schmitz \\ Rutgers University, U.S.A.
}

\begin{abstract}
This article inquires into the factors that affect the pricing of new issues of corporate tax-exempt bonds backed by standby letter of credit of U.S. and foreign commercial banks. Previous literature suggests that U.S. banks possess superior certifying ability in this market due to their unique access to low-cost private information. This article also examines the extent to which such information is priced by the market. The results indicate that pricing of these bonds depends primarily on the quality of the commercial bank issuing the standby letter of credit irrespective of where the bank is domiciled. The quality influence on yield occurs indirectly through its significant effect on the issue's bond rating (JEL G21).
\end{abstract}

Keywords: bank certification, industrial revenue bond financing, Moody's bond rating, standby letter of credit.

\section{Introduction}

Considerable research has focused on the certification of new security issues in terms of reducing the market uncertainty of future cash flows of the publicly held company. The quality of both investment bankers and auditors has been a principal determinant of this certification benefit as evidenced by reduced underpricing of initial public offerings. ${ }^{1}$

1. See, for example, Beatty and Ritter (1986), Carter and Manaster (1990), Beatty (1989), Michaely and Shaw (1995), and Titman and Trueman (1986).

(Multinational Finance Journal, 1997, vol. 1, no. 4, pp. 309-324)

(C) by Multinational Finance Society, a nonprofit corporation. All rights reserved. DOI: $10.17578 / 1-4-4$ 
Several articles concluded that commercial banks create unique incremental certification value for new issues due to their particular access to low- cost private information. ${ }^{2}$ A bank's long-standing relationship with the client yields this incremental value. However, these articles have not been able to empirically answer whether the market recognizes this unique feature in security pricing.

This article inquires into the factors that affect the pricing of new issues of corporate tax-exempt bonds backed by bank standby letters. ${ }^{3}$ Several articles suggest that location is an important determinant in a bank's relationship with a commercial client. Calomiris and Carey (1994) find that foreign banks' relationships with borrowing clients are generally arm's length when compared to those of U.S. banks. Saunders (1994) provides similar findings. As a result, foreign banks do not have access to private information. Puri (1996) reports that U.S. banks underwriting foreign bonds in the 1920s did not provide certification benefits because of prior lending relationships with the issuing entities. An important question addressed in this article is whether the market differentiates between U.S. and foreign banks issuing standby letters of credit in the pricing of corporate tax-exempt bonds. Other things being equal, underpricing of bonds backed by standby letters of credit of U.S. banks as opposed to foreign banks would suggest a market response to private information. ${ }^{4}$

Section II provides a review of the literature. Section III presents the empirical model and describes the sample used in this article. The model accounts for both the direct market response to the bank issuing the letter of credit and the indirect response through the role of the rating agency in municipal bond pricing. Section IV reports the empirical results. Section V presents the concluding remarks.

\section{Institutional and Literature Background}

Municipalities issue industrial development and pollution control bonds on behalf of individual firms. A standby letter of credit issued by a

2. See, for example, Damond $(1989,1991)$ and Fama (1985). Empirical announcement literature on lending relationships includes James and Wier (1990), Slovin and Young (1990), James (1987), Lummer and McConnell (1989), and Best and Zhang (1992).

3. With a standby letter of credit, the issuing bank guarantees bond payments to the holder in case of bond default.

4. Underpricing is measured in terms of the issue's true interest cost. 
bank provides one form of credit enhancement for these bonds. At the time of the bond issue, the bank normally requires a promissory note and a loan agreement establishing the interest rate and other conditions for the loan that would be initiated in case the letter of credit is paid out to the holder of the bond and the bank is not immediately reimbursed. Clearly, the bank's credit risk is directly related to the financial viability of the firm. Even though the standby letter of credit represents a contingent obligation, it is structured like commercial loans with specified collateral by the firm, a repayment schedule, and other terms. Where foreign banks are involved, the municipality must submit legal opinions in both countries, stating the enforcement ability of the letter of credit in the event of failure on the part of the firm.

While evidence indicates a certification influence on the pricing of new equity issues, only a few articles investigate a similar effect on the market for debt instruments. In the equity markets, the certifying agents include commercial banks, investment bankers, auditors, and venture capital firms. The importance of these agents arises from a possible information asymmetry which exists between the agents and the investors, when little information is available on the firm issuing the equity. In the case of commercial banks, their importance arises from the fact that they have unique access to information on the borrowing client, e.g., Fama (1985), and Chemmanur and Fulghieri (1994). Such information permits banks to provide effective monitoring services.

The municipal bond market exhibits market thinness similar to that in the new-issue equity market, e.g., Robbins, Apostolou, and Stawser (1985), and Ingram, Raman, and Wilson (1989). This problem is particularly intense for industrial revenue and pollution control bonds. Only a few firms using such bonds are publicly traded. Many of these firms are subsidiaries for which the parent company relinquishes all financial responsibility. An established long-term relationship of these firms with a bank may lead to a standby letter of credit, which enhances the marketability of their bonds.

In issuing letters of credit, banks put their reputation capital (goodwill) at stake. Failure to honor commitments arising from standby letters of credit will adversely affect the credit rating of the bank and jeopardize its operations. Thus, the quality of the bank, as measured by its credit rating, is directly related to the certification value of bonds. ${ }^{5}$

5. The 1989 Standard and Poor's publication Municipal Finance Criteria states: "S\&P rates bank-supported debt on the basis of the bank's creditworthiness without regard to the issuer's credit quality." 
James (1988) finds that riskier banks are more active in the market for standby letters of credit. This was particularly relevant during the 1980s as standby letters of credit were considered off-balance sheet items. Koppenhaver and Stover (1991) find that banks consider standby letters of credit and bank capital as simultaneous decisions. That is, recognizing that standby letters of credit increase bank risk, banks respond by increasing their capital ratios. Implicit in these articles is the conclusion that the market for credit-enhanced debt does appear to be cognizant of the bank risk variable.

Puri (1996) examines the underwriting of foreign bonds by U.S. banks on the premise that prior lending relationships appeared to be of little importance in the decision making. Puri finds no significant difference in yields of foreign bonds underwritten by U.S. investment banks as opposed to foreign banks. As a result, Puri concludes that the lack of prior lending experience reduces the possibility of significant certification benefits.

On the other hand, Calomiris and Carey (1994) and Saunders (1994) indicate that foreign banks do not focus on long-term borrower relationships. If investors consider private information arising from bank customer relationship relevant, then the certification value of foreign banks should lower to that of U.S. banks.

\section{Empirical Model and Sample}

This section describes the data and the means by which the sample was constructed and elaborates on the empirical methodology. The sample includes corporate tax-exempt bond issues backed by standby letters of credit of U.S. or foreign commercial banks. The empirical model recognizes certain basic features of the relationship between the relevant parties in the bond offering. These parities are the letter of credit issuing bank, the borrowing entity, and the bondholder.

\section{A. Empirical Model}

This subsection presents a regression model of the yield (pricing) of taxexempt bonds issued by municipalities on behalf of firms and backed by standby letters of credit of U.S. or foreign commercial banks. This model consists of explanatory variables employed in previous bond pricing research, e.g., Kidwell, Sorenson, and Wachowitz (1987); Liu 
TABLE 1. Numerical Scale of Bond Rating Measurement

\begin{tabular}{lllr}
\hline Rating & Score & Rating & Score \\
\hline AAA & 20 & A3 & 14 \\
AA1 & 19 & BBB1 & 13 \\
AA2 & 18 & BBB2 & 12 \\
AA3 & 17 & BBB3 & 11 \\
A1 & 16 & BB1 & 10 \\
A2 & 15 & BB2 & 9 \\
\hline
\end{tabular}

Note: None of the bond ratings in the sample were below BB.

and Thakor (1984); and Puri (1996). The model is as follows:

$$
\begin{aligned}
\text { YIELD }_{i} & =\alpha_{0}+\alpha_{1} \text { MAT }_{i}+\alpha_{2} \text { CALL }_{i}+\alpha_{3} \text { SIZE }_{i} \\
& +\alpha_{4} I N T_{i}+\alpha_{5} \Delta I N T_{i}+\alpha_{6} \text { RATING }_{i} \\
& +\alpha_{7} \text { QUALITY }_{i}+\alpha_{8} \text { DGRADE }_{i} \\
& +\alpha_{9} U S_{i}+\alpha_{10} \text { QUALITY }_{i} \times U S_{i}+\varepsilon_{i}
\end{aligned}
$$

where $Y I E L D_{i}$ is the yield on bond $i, M A T_{i}$ is the natural logarithm of bond's years to maturity, $C A L L_{i}$ is a dummy variable taking the value of one for bonds with call provisions and the value of zero otherwise, $S I Z E_{i}$ is a proxy for size of issue, measured by the natural logarithm of dollar value of issue, $I N T_{i}$ is the weekly average yield on high grade municipal bonds at the time of offering of bond $i$ as measured by Standard and Poor's index of yields for municipal bonds, $\triangle I N T_{i}$ is the weekly change in $I N T_{i}, Q U A L I T Y_{i}$ is a measure of credit quality for the bank issuing the standby letter of credit for bond $i, \operatorname{RATING}_{i}$ is a numerical score based on Moody's rating of bond $i$ at the time of issue (see table 1), DGRADE is a dummy variable taking the value of one for banks that received a reduced bond rating during the period 1984-1988 and the value of zero otherwise, $U S_{i}$ is a dummy variable that takes the value of one for U.S. banks and the value of zero otherwise, and $\varepsilon_{i}$ is a random error term. ${ }^{6}$

6. The maturity $(M A T)$ and bond issue size (SIZE) variables are transformed using the natural logarithm to capture non-linearities observed in previous studies as well as to 
In the above model, the maturity variable $(M A T)$ is intended to capture the shape of the yield curve for municipal bonds. The yield curve for municipal debt interest rates postulates a positive relation between MAT and YIELD. The CALL variable provides an adjustment to the model for callable bonds. The size variable is used as a proxy for marketability (liquidity) and potential economies of scale for the issue. Moreover, as Puri (1996) noted, larger bond issues are related to less uncertainty than smaller issues. Thus, other things being equal, larger issues will be associated with lower bond yields. The non-linearity for SIZE is based on the assumption that such scale economies deteriorate for very large issues.

The variable INT accounts for the impact of market interest rates for municipal bonds. The relation between INT and yields for bond $i$ $\left(Y I E L D_{i}\right)$ is expected to be positive. Consistent with Hopewell and Kaufman (1977), the volatility of interest rates $(\triangle I N T)$ is measured as the percentage change in Standard and Poor's Index from the previous week. Finally, the call provision $(C A L L)$ is entered as a dummy variable with one representing the existence of the call provision.

Moody's rating for each bank's senior unsecured or subordinate debt is a measure of bank quality. Another measure of quality - used in previous studies for new security pricing - is bank reputation. Following Koppenhaver and Stover (1991), the bank's asset size and profitability are used to proxy for its reputation. The latent variable QUALITY is constructed using the aforementioned measures and the statistical method of factor analysis; see Long (1983). A negative relationship is expected between bank QUALITY and bond YIELD. In addition to $Q U A L I T Y$, the dummy variable $D G R A D E$ is used to capture possible effect on changes in the bank's rating on YIELD.

Most municipal bond pricing research used bond rating as an explanatory variable for bond yield. A negative relation is expected between the RATING variable and bond yield. In contrast to previous studies that have exclusively looked at rating as an exogenous variable, we examine its additional role as a means of potentially transmitting the certification influence of the banks issuing the standby letter of credit. To allow for the possibility of simultaneous equation bias (Gande et al., 1997) involving the RATING variable, RATING of bond is modeled as a function of variables related to the credit quality of the bank issuing

minimize the effect of outlier values on the results. The construction of the RATING variable is similar to that of Barclay and Smith (1995) and Billett, Flannery, and Garfinkel (1995). 
the standby letter of credit as follows:

$$
\begin{aligned}
\text { RATING }_{i} & =\beta_{0}+\beta_{1} \text { QUALITY }_{i}+\beta_{2} D G R A D E_{i} \\
& +\beta_{4} U S_{i}+\beta_{5} \text { QUALITY }_{i} \times U S_{i}+u_{i}
\end{aligned}
$$

where the error term $u_{i}$ is orthogonal to all the explanatory variables in (2) and as such it represents the component of bond rating not related to the quality variables for the certifying bank. To allow for the possible endogenous RATING effect, the residuals from the above regression equation, denoted as RATRES, are used in place of the RATING variable of equation 1.

\section{B. Sample}

The sample includes 116 industrial development and pollution control bonds issued by municipalities on behalf of firms during the period 1986 through 1989. All these bonds are backed by standby letters of credit of U.S. or foreign commercial banks. This period was selected because of the dramatic changes that occurred, particularly in the composition of banks issuing the standby letters of credit; see Zimmer and McCauley (1991). The sample includes a large number of bonds backed by Japanese banks. ${ }^{7}$ Other characteristics of the samples, including issue size, maturity, and the existence of call provisions, were utilized to control for considerations identified in previous bond pricing research. All bonds have complete information on the variables used in equations 1 and 2 .

Table 2 presents some descriptive statistics on the variables for bonds backed (enhanced) by standby letters of credit issued by U.S. and non-U.S. commercial banks. The mean rating for bonds backed by U.S. banks is 18.37 and is significantly lower than the mean rating of bonds backed by foreign banks, which is 19.56. This difference is attributed to the fact that the quality of U.S. banks is generally lower than that of

7. In contrast to their performance in international financial markets, considerable research on the role of Japanese commercial banks in the Japanese markets has focused on their distinctive role in the governance of nonfinancial firms. Even with the considerable increase in public bond offerings in Japan in the past decade, the predominant source of funding continues to be borrowing from financial institutions. According to Calomiris and Carey (1994), a similar pattern of a close relationship between Japanese banks and commercial borrowers has not developed in the U.S. market. 
TABLE 2. Descriptive Statistics

\begin{tabular}{lrrrrr}
\hline \multirow{2}{*}{ Variable } & \multicolumn{2}{l}{ U.S. Banks } & \multicolumn{4}{l}{ Foreign Banks } \\
& Mean & STD & Mean & STD & T-STAT \\
\hline MAT & 2.27 & .81 & 2.40 & .74 & .38 \\
SIZE & .76 & 1.39 & .87 & 1.79 & .39 \\
INT & -.04 & .20 & -.08 & .03 & $3.30^{*}$ \\
RATING & 18.38 & 1.30 & 19.56 & .81 & $6.40^{*}$ \\
QUALITY & 15.88 & 1.98 & 20.68 & 2.71 & $10.92^{*}$ \\
DGRADE & .42 & .50 & .25 & .44 & -1.91 \\
\hline
\end{tabular}

Note: MAT is the natural logarithm of bond's years to maturity, SIZE is a proxy for size of issue, measured by the natural logarithm of dollar value of issue, INT is the weekly average yield on high-grade municipal bonds at the time of offering of the bond, as measured by the Standard and Poor's index of yields for municipal bonds, RATING is a numerical score based on Moody's rating of the bond at the time of issue (see table 1), QUALITY is a measure of credit quality for the bank issuing the standby letter of credit for the bond, DGRADE is a dummy variable taking the value of one for banks that received a reduced bond rating during the period 1984-1988 and the value of zero otherwise, and STD is the standard deviation. T-STAT is the $t$-statistic for testing the difference in the means between U.S. and foreign banks. *Significant at the $1 \%$ level.

foreign banks, as evidenced by the significantly lower mean of QUALITY variable for U.S. banks. In contrast, bonds backed by U.S. banks are usually offered in less volatile markets. The variables SIZE, $M A T$, and DGRADE are not statistically different in the two groups.

\section{Empirical Results}

The main focus of the empirical analysis is whether there is evidence of a bank location effect in the pricing of the corporate tax-exempt bonds backed by bank standby letters of credit. Based on the previous literature, this stage examines how the bond pricing responds to variations in the quality of the bank as a substitute for that of the issuer. Table 3 presents the correlation matrix for the relevant variables in the model. The significant negative correlation between QUALITY and $\triangle I N T$ indicates that higher-quality banks avoid issuing standby letters of credit during volatile bond markets. As expected, the variables of RATING and QUALITY are positively correlated, thus confirming the industry evidence of a direct relationship between bond rating and the quality of the bank certifying the bond issue. 
TABLE 3. Pearson Correlation Coefficients: Period 1986-1989

\begin{tabular}{|c|c|c|c|c|c|c|c|c|}
\hline & YIELD & $M A T$ & $C A L L$ & SIZE & $\triangle I N T$ & $R A T I N G$ & QUALITY & $U S$ \\
\hline$M A T$ & $.23 \#$ & & & & & & & \\
\hline$C A L L$ & -.16 & $-.24 * *$ & & & & & & \\
\hline SIZE & .10 & $.53 * *$ & $-.33 * *$ & & & & & \\
\hline$\triangle I N T$ & .08 & $.21 * *$ & .05 & $.33 * *$ & & & & \\
\hline RATING & -.16 & -.01 & -.14 & .01 & $-.44 * *$ & & & \\
\hline QUALITY & -.01 & -.06 & -.08 & -.03 & $-.40 * *$ & $.70 * *$ & & \\
\hline$\tilde{U S}$ & -.11 & -.11 & -.04 & -.04 & $.29 * *$ & $-.54 * *$ & $-.71 * *$ & \\
\hline$D G R A D E$ & -.01 & -.16 & .06 & $-.29 * *$ & .13 & -.07 & $.19 *$ & $.25^{* *}$ \\
\hline Mean & 7.03 & 2.32 & .96 & .78 & -.04 & 19.26 & 19.20 & .31 \\
\hline STD & 1.35 & .76 & .20 & 1.68 & .22 & 1.09 & 3.14 & .46 \\
\hline
\end{tabular}

Note: YIELD is the bond yield, MAT is the natural logarithm of bond's years to maturity, CALL is a dummy variable taking the value of one for bonds with call provisions and the value of zero otherwise, SIZE is a proxy for size of issue, measured by the natural logarithm of dollar value of issue, $I N T$ is the weekly average yield on high-grade municipal bonds at the time of offering of the bond, as measured by the Standard and Poor's index of yields for municipal bonds, $\triangle I N T$ is the weekly change in INT, QUALITY is a measure of credit quality for the bank issuing the standby letter of credit for the bond, $R A T I N G$ is a numerical score based on Moody's rating of the bond at the time of issue (see table 1), DGRADE is a dummy variable taking the value of one for banks that received a reduced bond rating during the period 1984-1988 and the value of zero otherwise, and US is a dummy variable that takes the value of one for U.S. banks and the value of zero otherwise. STD is for standard deviation. Number of observations is 116 . *Significan at the $1 \%$ level; **Significant at the $5 \%$ percent level, \#Significant at the $10 \%$ level. 
Prior to examining the direct influences on YIELD, we estimate equation 2 which suggests bond-rating agencies rely heavily on the bank issuing the standby letter of credit in rating credit-enhanced corporate tax-exempt bonds. The estimated equation is

$$
\begin{aligned}
\text { RATING }_{i} & =13.38+\underset{(6.63) *}{.311} \text { QUALITY }_{i}-\underset{(3.12) *}{.563} \text { DGRADE }_{i} \\
& +\underset{(.59)}{.157 U_{i}}+\underset{(.92)}{.059} \text { QUALITY }_{i} \times U S_{i}+\hat{u}_{i}
\end{aligned}
$$

$\operatorname{Adj}-R^{2}=.523$

The highly significant coefficient for the QUALITY variable provides strong, albeit indirect, evidence of certification benefits. The bond rating appears to respond to the quality of the certifying bank reflected in the higher bond rating after allowing for other influences. The coefficients for the US dummy variable and the $Q U A L I T Y \times U S$ interaction variable are both statistically insignificant, rejecting the hypothesis of differential private information effect on bond rating. That is, the U.S. banks do not exhibit any greater quality effect on the issue's bond rating than foreign banks. Moreover, the impact of bank quality on bond rating appears to be the same for U.S. and foreign banks.

The next issue to be examined is whether this bond market recognizes the information advantage of U.S. banks, given their general quality disadvantage relative to foreign banks. Table 4 presents the estimates for four variations of the regression model given by equation 1. The coefficient of the variables for MAT, CALL, INT, and RATING are statistically significant for all variations. Specifically, the coefficients for MAT and INT are negative, indicating a direct relationship between the bond yield with bond maturity and the market yield. The coefficients for CALL and RATING are negative, indicating an inverse relationship between the bond yield with the presence of the bond call provision and the bond rating. Neither the bank quality nor the bank rating downgrade variable are significant. The coefficient for the variable $U S$ is statistically insignificant, indicating no bank location effect on bond yields. Thus, the market does not directly respond to the location of the letter of credit-issuing bank. Similarly, the coefficient for the interaction term QUALITY and US location is statistically 
TABLE 4. Estimated Regression Models of Tax Exempt Bond Yields (YIELD) Backed by Bank Standby Letters of Credit

\begin{tabular}{|c|c|c|c|c|c|c|c|c|c|c|c|}
\hline Model & $M A T$ & $C A L L$ & SIZE & $I N T$ & $\triangle I N T$ & RATING & QUALITY & $D G R A D E$ & $U S$ & $\begin{array}{l}\text { QUALITY } \\
\times U S\end{array}$ & $R^{2}$ \\
\hline 1 & $\begin{array}{l}.355^{* *} \\
(.174)\end{array}$ & $\begin{array}{c}-1.232 * * \\
(.603)\end{array}$ & $\begin{array}{l}.120 \\
(.100)\end{array}$ & $\begin{array}{c}.955^{*} \\
(.206)\end{array}$ & $\begin{array}{l}-.720 \\
(.699)\end{array}$ & & $\begin{array}{l}-.021 \\
(.042)\end{array}$ & $\begin{array}{l}.136 \\
(.272)\end{array}$ & & & $.174 * *$ \\
\hline 2 & $\begin{array}{l}.364 * \\
(.171)\end{array}$ & $\begin{array}{c}-1.345^{* *} \\
(.595)\end{array}$ & $\begin{array}{l}.110 \\
(.098)\end{array}$ & $\begin{array}{c}.904^{*} \\
(.204)\end{array}$ & $\begin{array}{l}-.892 \\
(.691)\end{array}$ & $\begin{array}{l}-.338^{* *} \\
(.151)\end{array}$ & $\begin{array}{l}.060 \\
(.055)\end{array}$ & $\begin{array}{l}-.004 \\
(.275)\end{array}$ & & & $.206 * *$ \\
\hline 3 & $\begin{array}{l}.322 * \\
(.177)\end{array}$ & $\begin{array}{c}-1.442 * * \\
(.604)\end{array}$ & $\begin{array}{l}.114 \\
(.098)\end{array}$ & $\begin{array}{l}.841^{*} \\
(.215)\end{array}$ & $\begin{array}{c}-.922 \\
(.692)\end{array}$ & $\begin{array}{l}-.337 * * \\
(.151)\end{array}$ & $\begin{array}{l}.007 \\
(.078)\end{array}$ & $\begin{array}{c}.174 \\
(.333)\end{array}$ & $\begin{array}{l}-.429 \\
(.455)\end{array}$ & & $.203^{*}$ \\
\hline 4 & $\begin{array}{l}.284 \\
(.178)\end{array}$ & $\begin{array}{c}-1.596 * * \\
(.610)\end{array}$ & $\begin{array}{l}.095 \\
(.099)\end{array}$ & $\begin{array}{l}.785^{*} \\
(.217)\end{array}$ & $\begin{array}{l}-.795 \\
(.694)\end{array}$ & $\begin{array}{l}-.362 * * \\
(.151)\end{array}$ & $\begin{array}{l}.078 \\
(.092)\end{array}$ & $\begin{array}{l}.172 \\
(.332)\end{array}$ & $\begin{array}{l}-.668 \\
(.481)\end{array}$ & $\begin{array}{l}.153 \\
(.104)\end{array}$ & $.211 *$ \\
\hline
\end{tabular}

Note: $M A T$ is the natural logarithm of bond's years to maturity, $C A L L$ is a dummy variable taking the value of one for bonds with call provisions and the value of zero otherwise, SIZE is a proxy for size of issue, measured by the natural logarithm of dollar value of issue, INT is the weekly average yield on high-grade municipal bonds at the time of offering of the bond, as measured by the Standard and Poor's index of yields for municipal bonds, $\triangle I N T$ is the weekly change in INT, RATING is a numerical score based on Moody's rating of the bond at the time of issue (see table 1 ), QUALITY is a measure of credit quality for the bank issuing the standby letter of credit for the bond, DGRADE is a dummy variable taking the value of one for banks that received a reduced bond rating during the period 1984-1988 and the value of zero otherwise, and US is a dummy variable that takes the value of one for U.S. banks and the value of zero otherwise. Parentheses include the standard errors for the estimates. Number of observations is 116. *Significant at the $1 \%$ level. **Significant at the $5 \%$ percent level. \#Significant at the $10 \%$ level. 
TABLE 5. Estimated Regression Models of Tax Exempt Bond Yields (YIELD) Backed by Bank Standby Letters of Credit

\begin{tabular}{|c|c|c|c|c|c|c|c|c|c|c|c|}
\hline Model & $M A T$ & $C A L L$ & SIZE & $I N T$ & $\triangle I N T$ & RATRES & QUALITY & $D G R A D E$ & $U S$ & $\begin{array}{l}\text { QUALITY } \\
\times U S\end{array}$ & $R^{2}$ \\
\hline 1 & $\begin{array}{l}.355^{* *} \\
(.174)\end{array}$ & $\begin{array}{c}-1.232 * * \\
(.603)\end{array}$ & $\begin{array}{l}.120 \\
(.100)\end{array}$ & $\begin{array}{l}.955^{*} \\
(.206)\end{array}$ & $\begin{array}{l}-.720 \\
(.699)\end{array}$ & & $\begin{array}{l}-.021 \\
(.042)\end{array}$ & $\begin{array}{c}.136 \\
(.272)\end{array}$ & & & $.174 * *$ \\
\hline 2 & $\begin{array}{l}.367^{*} \\
(.171)\end{array}$ & $\begin{array}{c}-1.347 * * \\
(.594)\end{array}$ & $\begin{array}{l}.106 \\
(.098)\end{array}$ & $\begin{array}{c}.909^{*} \\
(.203)\end{array}$ & $\begin{array}{c}-.871 \\
(.689)\end{array}$ & $\begin{array}{c}-.343 * * \\
(.151)\end{array}$ & $\begin{array}{c}-.026 \\
(.041)\end{array}$ & $\begin{array}{l}.152 \\
(.267)\end{array}$ & & & $.204 * *$ \\
\hline 3 & $\begin{array}{l}.318^{*} \\
(.176)\end{array}$ & $\begin{array}{c}-1.468^{* *} \\
(.603)\end{array}$ & $\begin{array}{l}.111 \\
(.098)\end{array}$ & $\begin{array}{l}.831^{*} \\
(.214)\end{array}$ & $\begin{array}{c}-.913 \\
(.689)\end{array}$ & $\begin{array}{l}-.357 * * \\
(.152)\end{array}$ & $\begin{array}{l}-.090 \\
(.070)\end{array}$ & $\begin{array}{c}.368 \\
(.328)\end{array}$ & $\begin{array}{l}-.518 \\
(.457)\end{array}$ & & $.207^{*}$ \\
\hline 4 & $\begin{array}{c}.284 \\
(.176)\end{array}$ & $\begin{array}{c}-1.596^{* *} \\
(.610)\end{array}$ & $\begin{array}{c}.095 \\
(.098)\end{array}$ & $\begin{array}{c}.785^{*} \\
(.217)\end{array}$ & $\begin{array}{l}-.795 \\
(.694))\end{array}$ & $\begin{array}{l}-.362 * * \\
(.151)\end{array}$ & $\begin{array}{l}-.034 \\
(.082)\end{array}$ & $\begin{array}{l}.376 \\
(.327\end{array}$ & $\begin{array}{c}-.725 \\
(.483)\end{array}$ & $\begin{array}{c}-.132 \\
(.104)\end{array}$ & $.211^{*}$ \\
\hline
\end{tabular}

Note: $M A T$ is the natural logarithm of bond's years to maturity, $C A L L$ is a dummy variable taking the value of one for bonds with call provisions and the value of zero otherwise, SIZE is a proxy for size of issue, measured by the natural logarithm of dollar value of issue, INT is the weekly average yield on high-grade municipal bonds at the time of offering of bond $i$ as measured by the Standard and Poor's index of yields for municipal bonds, $\triangle I N T$ is the weekly change in INT, RATRES residuals from the bond rating equation 2, QUALITY is a measure of credit quality for the bank issuing the standby letter of credit for the bond, $D G R A D E$ is a dummy variable taking the value of one for banks that received a reduced bond rating during the period 19841988 and the value of zero otherwise, and US is a dummy variable that takes the value of one for U.S. banks and the value of zero otherwise. Parentheses include the standard errors for the estimates. Number of observations is 116 . *Significant at the $1 \%$ level. **Significant at the $5 \%$ percent level. \#Significant at the $10 \%$ level. 
insignificant.

The insignificance of the QUALITY and locations variables may be attributed to the interaction between the RATING and QUALITY variables as indicated by the results of equation 2 . To examine this possibility, the RATING variable in equation 1 is replaced by the regression residuals of equation 2, RATRES. The estimates for the four variations using the RATRES variable are presented in table 5. While the magnitude of the coefficients in the model is slightly different from those in table 4, the results are still the same.

\section{Conclusions}

Previous research examining the role of standby letters of credit has focused principally on explaining the volume of activity in this market and related bank risk. Little attention has been given to assessing certification issues from the perspective of market pricing in the related markets. The return to the letter of credit issuing bank depends on the level of inside information and/or the costs of achieving such information through the due diligence process. In previous literature, the assumption has been that non-U.S. banks find this information search to be more expensive, given their relatively little direct interaction with U.S. firms. Earlier studies have not explicitly attempted to quantify this issue. The main issue addressed in this article is whether this location variable affects the bond pricing (yields).

The results indicate that the quality of the bank issuing the standby letter of credit is the principal test variable affecting the yields of the sampled issues. The quality influence on yield occurs indirectly through its significant effect on the issue's bond rating. The lack of significance for the location variable suggests that the relative due diligence efficiency for U.S. compared to non-U.S. was not apparent in the yields. Thus, investors recognize the value added from the guarantee and only indirectly the inside information advantage unique to U.S. banks.

These results provide additional information that may influence the considerations surrounding the choice involved in a standby letter of credit. It is apparent in this sector of the debt markets that the bank quality, as broadly defined in this study, is an important variable in the pricing of credit-enhanced bonds. For the sample in this study, the average quality of the letter of credit-issuing banks was lower in the 
United States. Therefore, issuing entities may be inclined to utilize better rated international banks. The results of this study suggest that such a decision may be appropriate. However, such a conclusion must recognize that the fee structure for the letters of credit may affect this quality-location tradeoff. Because no evidence currently exists to suggest a systematically different structure among international banks, we will leave this to future research.

\section{References}

Barclay, M., and Smith, C. 1995. The maturity structure of corporate debt. Journal of Finance 50: 609-631.

Beatty, R. 1989. Auditor reputation and the pricing of initial public offerings. Accounting Review 64: 693-709.

Beatty, R., and Ritter, J. 1986. Investment banking, reputation, and the underpricing of initial public offerings. Journal of Financial Economics 15: 213-232.

Best, R., and Zhang, H. 1992. Alternative information sources and the information content of bank loans. Journal of Finance 48: 507-522.

Billett, M.; Flannery, M.; and Garfinkel, S. 1995. The effect of lender identity on a borrowing firm's equity return. Journal of Finance 50: 699-718.

Calomiris, C., and Carey, M. 1994. Loan market competition between foreign and U.S. banks: Some facts about loans and borrowers. Working paper. New York: Columbia University.

Carter, R., and Manaster, S. 1990. Initial public offerings and underwriter reputation. Journal of Finance 45: 1045-1067.

Carter, R.; Dark, R.; and Singh, A. 1998. Underwriter reputation, initial returns, and long-run performance of IPO stocks. Journal of Finance 53: 285-312.

Chemmanur, T., and Fulghieri, P. 1994. Reputation, renegotiation, and the choice between bank loans and publicly traded debt. Review of Financial Studies 7: 475-506.

Diamond, D. 1989. Reputation acquisition in debt markets. Journal of Political Economy 97: 828-862.

Diamond, D. 1991. Monitoring and reputation. The choice between bank loans and directly placed debt. Journal of Political Economy 99: 689-721.

Fama, E. 1985. What's different about banks? Journal of Monetary Economics 15: 29-39.

Gande, A.; Puri, M.; Saunders, A.; and Walter, I. 1997. Bank underwriting of debt securities: Modern evidence. Review of Financial Studies: 10: 11751202.

Goldberg, A., and Duncan, O. 1973. Structural Equation Models in the Social Sciences. New York: Academic Press. 
Ingram, R.; Raman, K.; and Wilson, E. 1989. The information in governmental annual reports: A contemporaneous price reaction approach. The Accounting Review: 250-268.

James, C. 1987. Some evidence on the uniqueness of bank loans. Journal of Financial Economics 18: 217-235.

James, C. 1988. The use of loan sales and standby letters of credit by commercial banks. Journal of Monetary Economics 22 (November): 395422.

James, C., and Wier, P. 1990. Borrowing relationships, intermediation, and the cost of issuing public securities. Journal of Financial Economics 28: 149171.

Kanatas, G. 1987. Commercial paper, bank reserve requirements, and the informational role of loan commitments. Journal of Banking and Finance 11: 425-448.

Kidwell, D.; Sorenson, E.; and Wachowitz, J. 1987. Estimating the signaling benefits of debt insurance: The case of municipal bonds. Journal of Financial and Quantitative Analysis 22: 299-313.

Koppenhaver, G. D., and Stover, R. April 1991. Standby letters of credit and large bank capital: An empirical analysis. Journal of Banking and Finance 15: 315-327.

Liu, P., and Thakor, A. 1984. Interest yields, credit ratings, and economic characteristics of state bonds: An empirical analysis. Journal of Money, Credit, and Banking 16: 344-351.

Long, J. 1983. Confirmatory Factor Analysis. Beverly Hills, CA: Sage Publications.

Lummer, S., and McConnell, J. 1989. Further evidence on the bank lending process and the capital market response to bank loan agreements. Journal of Financial Economics 25: 99-122.

Megginson, W., and Weiss, K. July 1991. Venture capital certification in initial public offerings. Journal of Finance 46: 879-903.

Merton, R., and Brodie, Z. 1992. On the management of financial guarantees. Financial Management 21: 87-109.

Michaely, R., and Shaw, W. Spring 1995. Does the choice of auditor convey quality in an initial public offering? Financial Management 24: 15-30.

Millon, M., and Thakor, A. 1985. Moral hazard and information gathering: A model of financial information-gathering agencies. Journal of Finance 40: 1403-1422.

Puri, M. 1996. Commercial banks in investment banking: Conflict of interest or certification role? Journal of Financial Economics 40: 373-401.

Robbins, W.; Apostolou, N.; and Stawser, R. 1985. Municipal annual reports and the information needs of investors. Journal of Accounting, Auditing, and Finance 8: 279-292.

Saunders, A. 1994. Financial Institutions Management. New York: Irwin.

Slovin, M., and Young, J. 1990. Bank lending and initial public offerings. 
Journal of Banking and Finance 14: 729-740.

Standard and Poor's Municipal Finance Criteria. Standard and Poor's, Inc., 1991.

Thakor, A. 1982. An exploration of competitive signaling equilibria with 'third party' information production: The case of debt insurance. Journal of Finance 37: 717-740.

Titman, S., and Trueman, B. June 1986. Information quality and the valuation of new issues. Journal of Accounting and Economics 8: 159-172.

Wakeman, L. M. 1981. The real function of bond rating agencies. Chase Financial Quarterly: 18-26.

Zimmer, S., and McCauley, R. 1991. Bank cost of capital and international competition. Quarterly Review (Spring): 33-59. New York: Federal Reserve Bank of New York. 